\title{
Incidence and Population Density of Plant-Parasitic Nematodes Associated with Olive Planting Stocks at Nurseries in Southern Spain
}

\author{
A. I. Nico, Graduate Student, Instituto de Agricultura Sostenible, Consejo Superior de Investigaciones Científicas \\ (IAS-CSIC), Apdo. 4084, 14080-Córdoba, Spain; H. F. Rapoport, Tenure Scientist, IAS-CSIC; R. M. Jiménez- \\ Díaz, Professor, IAS-CSIC and Escuela Técnica Superior de Ingenieros Agrónomos y Montes (ETSIAM), Univer- \\ sidad de Córdoba, Apdo. 3048, 14080 Córdoba, Spain; and P. Castillo, Research Nematologist, IAS-CSIC
}

\begin{abstract}
Nico, A. I., Rapoport, H. F., Jiménez-Díaz, R. M., and Castillo, P. 2002. Incidence and population density of plant-parasitic nematodes associated with olive planting stocks at nurseries in southern Spain. Plant Dis. 86:1075-1079.

Nematode population densities were determined in 259 soil and root samples collected from 18 olive nurseries in Córdoba, Jaén, and Sevilla provinces (southern Spain), between October 1997 and May 1998. The most important plant-parasitic nematodes detected, in order of decreasing frequency of infestation (percentage of samples), were Mesocriconema xenoplax (39.0\%), Pratylenchus penetrans $(32.1 \%)$, P. vulnus (25.9\%), Meloidogyne incognita (14.7\%), M. javanica $(11.2 \%)$, and $M$. arenaria (2.7\%). No disease symptoms were noted on aboveground organs of infected plants. However, population densities of Pratylenchus and Meloidogyne spp. were at potentially damaging levels in most of the olive nurseries surveyed. Histopathological studies of galled roots from the naturally infected olive planting stocks showed a susceptible response to root-knot nematode infection. Large numbers of egg masses were present within the galled root tissues that might contribute to secondary infections. Feeding by root-knot nematodes induced the expected cellular alterations in the cortex, endodermis, pericycle, and vascular system, including giant-cell formation and the alteration of vascular tissues.
\end{abstract}

Additional keywords: dagger nematodes, Helicotylenchus spp., host-parasite relationships, migratory ectoparasitic nematodes, Olea europaea, pin nematodes, ring nematodes, root-lesion nematodes, stubby-root nematodes

Olive (Olea europaea L. subsp. europaea), an evergreen tree native to western Asia, is extensively grown in the Mediterranean Basin, the subtropical regions of Australia, southern Africa, and North and South America. Some 750 million trees are grown on approximately 8.5 million ha, of which about $97 \%$ are in Mediterranean countries (8). In Andalucía, southern Spain, olive trees cover more than $1.3 \times$ $10^{6}$ ha (2). In this region, planting of new orchards has increased steadily during the last decade, associated with the innovation and improvement of plant propagation techniques (such as rooting of leafy stem cuttings under mist tunnels) which facili-

Corresponding author: P. Castillo

E-mail: ag1cascp@uco.es

Research was supported in part by grant CAO99-010-C3-01 from Instituto Nacional de Investigación y Tecnología Agraria y Alimentaria (INIA) of Spain and 1FD97-1322-C04-02 from Comisión Interministerial de Ciencia y Tecnología of Spain. Research stay in Spain of the A. I Nico was financially supported by a grant from the AECI (Agencia Española de Cooperación Internacional).

Accepted for publication 15 May 2002.

Publication no. D-2002-0722-02R

(C) 2002 The American Phytopathological Society tate the rapid production of homogenous commercial planting stocks (6).

In order to obtain commercial 8- to 10month-old planting stocks, plants are grown individually in 2 to 3 liters of soil in plastic bags for several months. This soil originates from either diluvial sandy soil or loamy field soil. These natural soils can be potentially infested with soilborne pathogens, including Verticillium dahliae Kleb. (the causal agent of Verticillium wilt) $(3,30)$ and plant-parasitic nematodes. In addition, $V$. dahliae can be spread by infected planting material (33). Thus, the use of pathogen-free planting material and uninfested soil during olive plant propagation is essential for minimizing the effects of single or concomitant infections by soilborne pathogens during the early years of olive cultivation and for preventing pathogen spread (18). The damaging potential of these events to olive production was recognized by Spanish $(4,5)$ and European Union (EU) legislations (29) by mandated certification schemes for pathogentested olive trees and rootstocks (29).

Several plant-parasitic nematodes have been found associated with olive trees, including Mesocriconema xenoplax (Raski) Loof \& De Grisse (= Criconemella xenoplax (Raski) Luc \& Raski), Helicotylenchus spp., Meloidogyne spp., and Pratylenchus spp. (10,23). Conversely, limited distribution was reported for the citrus nematode Tylenchulus semipenetrans Cobb and the cyst-forming nematode Heterodera mediterranea Vovlas, Inserra, and Stone $(7,16,26)$. Nevertheless, little information is available about plantparasitic nematodes in olive nurseries in the Mediterranean Basin (15,35), as well as the host-parasite relationships between root-knot nematodes and olive planting stocks. Consequently, the objectives of this study were to (i) determine the identity, frequency, and population density of plant-parasitic nematodes in olive planting stocks in the key olive-producing provinces of Andalucía (southern Spain) and (ii) study the host-parasite relationship in naturally infected root-knot nematode olive planting stocks.

\section{MATERIALS AND METHODS}

Nematode survey. Eighteen commercial olive nurseries in Córdoba, Jaén, and Sevilla provinces of Andalucía, which represent about $25 \%$ of the total number of commercial olive nurseries in Spain, were selected for nematode surveys. Inspected nurseries were selected on the basis of their commercial importance (i.e., total number of olive planting stocks produced per year), soil type utilized for growth and main-

Table 1. Physicochemical characteristics of soil in olive nurseries at Andalucía, southern Spain ${ }^{\mathrm{a}}$

\begin{tabular}{lclccc}
\hline Province & Nurseries (no.) & Soil texture & Sand $(\boldsymbol{\%})$ & $\mathbf{p H}$ & Organic matter (\%) \\
\hline Córdoba & 4 & Sandy loam & 80.5 & 8.47 & 0.46 \\
Córdoba & 2 & Loamy sand & 75.7 & 8.44 & 0.45 \\
Córdoba & 3 & Loam & 38.4 & 8.10 & 1.22 \\
Sevilla & 3 & Clay loam & 31.6 & 7.93 & 2.01 \\
Jaén & 1 & Loamy sand & 58.4 & 8.20 & 1.15 \\
Jaén & 2 & Loam & 23.4 & 7.94 & 1.04 \\
Jaén & 3 & Silty clay loam & 22.6 & 8.30 & 2.02 \\
\hline
\end{tabular}

a Soil analysis of olive nurseries were determined by the Regional Agricultural Laboratory at Córdoba. 
tenance of planting stocks at the nursery, and geographic distribution of nurseries. Analyses of texture and composition of soil in each nursery were carried out by the
Regional Agricultural Laboratory at Córdoba (Table 1).

The plants were grown in each nursery, using that nursery's plant material and soil substrate, in standard 15-cm-diameter black plastic bags (one plant per bag) containing 2 to 3 liters of soil (Fig. 1A). Most of the planting stocks were grown out in
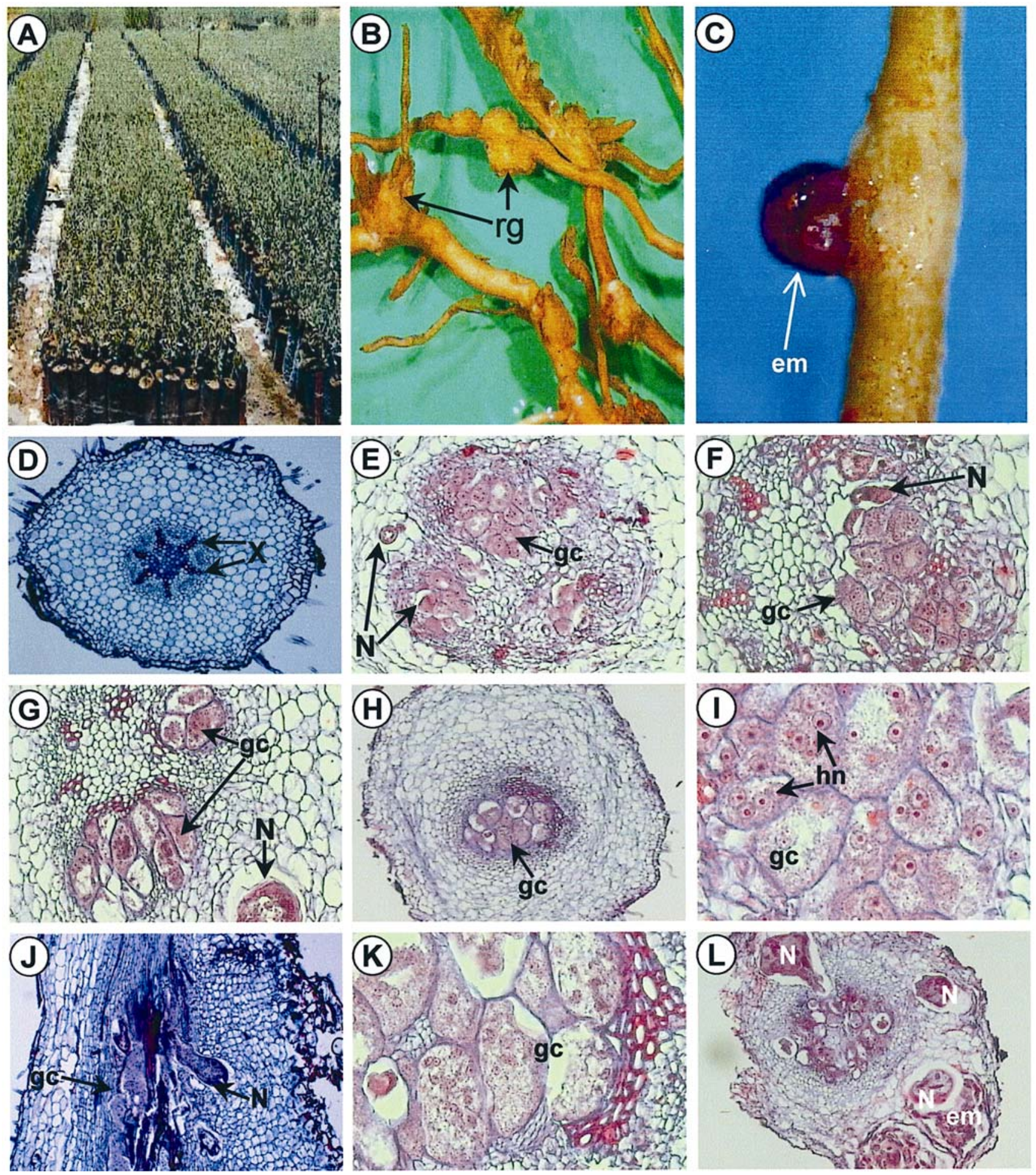

Fig. 1. A, Typical view of nursery for production of olive planting stock in southern Spain; $\mathbf{B}$, olive planting stocks infected by Meloidogyne sp. $(\mathrm{rg}=\mathrm{root}$ gall); C, root of an olive planting stock with an external egg mass (em); D, transverse section of a young, healthy olive root (cv. Picual); the xylem (X) poles of the stele are separated by regions of regular, small-celled vascular parenchyma. $\mathbf{E}$ and $\mathbf{F}$, Transverse sections of roots of olive planting stock (cv. Picual) infected by $M$. incognita and $M$. javanica, respectively; feeding by the nematode female $(\mathrm{N})$ has stimulated the formation of giant cells (gc) and disrupted the vascular parenchyma. $\mathbf{G}$ and $\mathbf{H}$, Transverse sections of roots of olive planting stock (cv. Arbequina) infected by M. incognita and $M$. javanica, respectively; presence of nematodes $(\mathrm{N})$ in the cortex and giant cells $(\mathrm{gc})$ in the vascular stele. I, Transverse section of root of olive planting stock root (cv. Hojiblanca) infected by M. incognita; numerous giant cells ( $\mathrm{gc}$ ) with characteristic dense cytoplasm and multiple hypertrophied nuclei (hn). $\mathbf{J}$, Longitudinal section of root of olive planting stock (cv. Hojiblanca) infected by M. javanica; giant cells (gc) adjacent to vascular tissues and mature female (N). K, Transverse section of root of olive planting stock root (cv. Manzanilla) infected by M. javanica; the formation of large, multi-nucleate giant cells (gc) has crushed and distorted the xylem tissue (X). L, Transverse section of root of olive planting stock (cv. Cornicabra) severely infected by $M$. arenaria; the mature female $(\mathrm{N})$ producing egg masses $(\mathrm{em})$ inside the root cortex. 
the open (Fig. 1A), but a few were kept under a shade-cloth mesh. In all nurseries, the plants were watered automatically by sprinkler irrigation (Fig. 1A) and fertilized with Osmocote-Mini (Scotts-Sierra Horticultural Products, Heerten, The Netherlands) at 6 to $8 \mathrm{~g} / \mathrm{bag}$ introduced at the time of planting, and the soil was kept free from weeds by manual removal. The planting stocks were maintained under these conditions for 4 to 12 months.

Every olive cultivar in an inspected nursery was sampled, with the total number of sampled plants proportional to the number of olive planting stocks produced per year in that nursery. Each sample consisted of a randomly chosen plastic bag and the included soil and olive planting stock. A total of 259 samples were collected between October 1997 and May 1998. The 259 samples belonged to olive cvs. Picual (102 samples), Arbequina (63 samples), Hojiblanca (39 samples), Manzanilla (27 samples), Cornicabra (21 samples), Gordal (3 samples), Ocal (3 samples), and $\mathrm{Pi}$ colimón (1 sample). Cultivars Arbequina, Hojiblanca, Manzanilla, and Picual are the most commonly grown in Andalucía (2).

Frequency of infestation and population density were determined. Frequency of nematode infestation was calculated as the percentage of samples or nurseries in which a nematode species was found. Nematode population densities in both root and soil were assessed for each sample. The complete root system was washed free of soil, weighed, and used to extract nematodes by maceration-centrifugation (9). Additionally, when roots of a sampled plant were galled, half of the root system of that plant was used to assess the egg population density of Meloidogyne spp. Meloidogyne eggs were collected from galled roots blended in a $0.5 \% \mathrm{NaOCl}$ solution for 4 min (13). For soil population density, the nematodes were extracted from a $100-\mathrm{cm}^{3}$ subsample of soil by centrifugal-flotation (9). Population densities of nematode species in soil and root samples were calculated as the averages of the total number of nematodes recorded for those samples in which a nematode species was found. Nematodes then were fixed in $4 \%$ formaldehyde and counted. Selected nematodes were processed to glycerin by Seinhorst's method (31) for species identification.

Identification of Meloidogyne spp. Populations of Meloidogyne spp. were increased on tomato (Lycopersicon esculentum Mill. cv. Roma) to obtain female perineal patterns for species verification. Tomato seedlings (4 to 6 weeks old) were transplanted (one per pot) into 1-liter clay pots filled with sterile clay loam soil. Seedlings then were inoculated by pipetting approximately 1,000 eggs in $10 \mathrm{ml}$ of sterile water into each pot. There were four inoculated seedlings per Meloidogyne sp. population. Pots were placed in a solid surface bench in a greenhouse adjusted to $25 \pm 5^{\circ} \mathrm{C}$. Pots with a nematode population were grouped together and groups were placed $1 \mathrm{~m}$ apart from each other. Sixty days after inoculation, plants were removed from the pots and the root systems washed free of soil and stained with Phloxine B (15 mg/liter of tap water) for $20 \mathrm{~min}$. Perineal patterns of mature females were prepared for each root-knot nematode population. The root tissues were teased apart with forceps and half spear to remove adult females. The head and neck region of the nematode was excised, and the posterior placed in a solution of $45 \%$ lactic acid to remove all body tissues. Then, the perineal pattern was trimmed and transferred to a drop of glycerine and processed as described by Hartman and Sasser (12). At least 20 perineal patterns were examined for identifying to species each Meloidogyne sp. population.

Histopathology. Galled roots from naturally infected olive planting stocks of cvs. Arbequina, Cornicabra, Hojiblanca, Manzanilla, and Picual were selected for histopathological studies. The roots were gently washed free of adhering soil and debris, and individual galls were selected as well as root segments of uninfected planting stocks. Galled and healthy root tissues were fixed in FAE (formalin:acetic acid: $60 \%$ ethanol $=2: 1: 17 \mathrm{vol} / \mathrm{vol}$ ) for $\mathrm{a}$ minimum of $48 \mathrm{~h}$, dehydrated in a tertiary butyl alcohol series (70, 85, 90, 100\%), and embedded in paraffin. Embedded tissues were sectioned longitudinally and transversely at 10 to $12 \mu \mathrm{m}$ with a rotary microtome, mounted on glass slides, stained with tannic acid, iron chloride, safranin, and fast-green (modified from Jensen, 17), mounted permanently, and observed with an optical microscope. Images were captured with a Leica QW5001 image processing system.

\section{RESULTS}

Nematode survey. Thirty-four species of plant-parasitic nematodes were found associated with olive planting stocks at nurseries in Andalucía, southern Spain (Table 2). Plant-parasitic nematodes were detected in 146 out of the 259 root samples and in all of the soil samples. Among spe-

Table 2. Frequency and population densities of plant-parasitic nematodes in soil and roots of olive planting stocks in Andalucía (southern Spain)a

\begin{tabular}{|c|c|c|c|}
\hline Nematode species & Frequency $^{\mathbf{b}}$ & $\begin{array}{l}\text { Nematodes/ } \\
100 \mathrm{~cm}^{3} \text { of soil }\end{array}$ & $\begin{array}{l}\text { Nematodes/ } \\
\text { g of root }\end{array}$ \\
\hline Mesocriconema xenoplax & 39.0 & $396.5 \pm 84.3$ & $9.2 \pm 3.2$ \\
\hline Tylenchorhynchus clarus & 39.0 & $79.1 \pm 7.8$ & $\ldots$ \\
\hline Helicotylenchus pseudorobustus & 34.0 & $59.0 \pm 6.2$ & $\ldots$ \\
\hline Pratylenchus penetrans & 32.1 & $93.6 \pm 11.6$ & $11.5 \pm 2.4$ \\
\hline Pratylenchus microdorus & 27.4 & $70.5 \pm 25.5$ & $2.6 \pm 1.6$ \\
\hline Pratylenchus vulnus & 25.5 & $66.3 \pm 6.6$ & $10.3 \pm 3.0$ \\
\hline Pratylenchus thornei & 22.8 & $36.7 \pm 4.8$ & $5.7 \pm 2.2$ \\
\hline Paratrichodorus teres & 20.1 & $47.7 \pm 5.6$ & $\ldots$ \\
\hline Meloidogyne incognita & 14.7 & $248.0 \pm 78.2$ & $1,367.2 \pm 642.0^{\mathrm{c}}$ \\
\hline Paratylenchus arculatus & 13.5 & $240.3 \pm 73.8$ & $47.9 \pm 24.2$ \\
\hline Helicotylenchus digonicus & 13.1 & $100.6 \pm 35.8$ & $\ldots$ \\
\hline Tylenchorhynchus dubius & 12.7 & $94.8 \pm 23.6$ & $\ldots$ \\
\hline Tylenchorhynchus sp. & 12.0 & $87.3 \pm 19.7$ & $\ldots$ \\
\hline Meloidogyne javanica & 11.2 & $191.6 \pm 29.7$ & $708.5 \pm 181.7^{\mathrm{c}}$ \\
\hline Paratrichodorus minor & 7.3 & $37.2 \pm 7.5$ & $\ldots$ \\
\hline Tylenchorhynchus huesingi & 5.8 & $110.1 \pm 25.2$ & $\ldots$ \\
\hline Xiphinema pachtaicum & 5.4 & $11.8 \pm 3.1$ & $\ldots$ \\
\hline Tylenchorhynchus aduncus & 4.6 & $69.4 \pm 31.9$ & \\
\hline Pratylenchus neglectus & 4.2 & $104.8 \pm 14.5$ & $8.4 \pm 2.8$ \\
\hline Helicotylenchus vulgaris & 3.9 & $154.1 \pm 134.5$ & 1.4 \\
\hline Zygotylenchus guevarai & 3.9 & $21.9 \pm 3.4$ & $4.5 \pm 1.9$ \\
\hline Tylenchorhynchus mamillatus & 3.5 & $57.0 \pm 13.7$ & $\ldots$ \\
\hline Meloidogyne arenaria & 2.7 & $1205.2 \pm 1062.7$ & $661.9 \pm 519.3^{\mathrm{c}}$ \\
\hline Pratylenchus fallax & 2.7 & $86.7 \pm 19.9$ & $1.5 \pm 0.5$ \\
\hline Amplimerlinius paraglobigerus & 1.9 & $22.2 \pm 6.2$ & $\ldots$ \\
\hline Longidorus sp. & 1.9 & $6.2 \pm 1.2$ & $\ldots$ \\
\hline Heterodera avenae & 1.5 & $64.5 \pm 49.0$ & $\ldots$ \\
\hline Criconemoides informis & 1.2 & $21.3 \pm 5.5$ & $\ldots$ \\
\hline Helicotylenchus dihystera & 1.2 & $779.0 \pm 668.7$ & $\ldots$ \\
\hline Hemicycliophora sp. & 1.2 & $7.0 \pm 2.5$ & $\ldots$ \\
\hline Trichodorus giennensis & 1.2 & $28.3 \pm 19.3$ & $\ldots$ \\
\hline Pratylenchoides ritteri & 0.8 & $14.5 \pm 6.5$ & \\
\hline Meloidogyne lusitanica & 0.4 & 643.0 & $2,856.0^{\mathrm{c}}$ \\
\hline Rotylenchus sp. & 0.4 & 8.0 & \\
\hline
\end{tabular}

${ }^{a}$ Data are the mean \pm standard error (SE) of nematodes per $100 \mathrm{~cm}^{3}$ soil and nematodes per $\mathrm{g}$ root in 259 soil and root samples collected in 18 olive nurseries in Córdoba, Jaén, and Sevilla provinces (southern Spain). Species presented in order of decreasing frequency; $\ldots=$ absence of nematode population of that species.

${ }^{\mathrm{b}}$ Frequency $=$ percentage of samples in which a nematode species was found.

c Numbers indicate eggs plus second-stage juveniles collected from galled roots blended in a $0.5 \%$ $\mathrm{NaOCl}$ solution for $4 \mathrm{~min}$. 
cies considered as potentially damaging for olive planting stocks, Mesocriconema. xenoplax, Pratylenchus penetrans (Rensch) Filipjev \& Schuurman Steckhoven, P. vulnus Allen \& Jensen, Meloidogyne arenaria (Neal) Chitwood, M. incognita (Kofoid \& White) Chitwood, M. javanica (Treub) Chitwood, and M. lusitanica Abrantes \& Santos, Helicotylenchus digonicus Perry, in Perry, Darling \& Thorne and $H$. dihystera (Cobb) Sher, were the most important found (Table 2). Frequency of these nematode species in soil and root samples ranged from 39.0 to $0.4 \%$, respectively (Table 2); however, frequency of those nematode species in the surveyed olive nurseries was 83.3, 66.7, 50.0, 16.7, 50.0, 16.7 , and $5.5 \%$, respectively.

No disease symptoms were observed on the stems or leaves of nematode-infected planting stocks as compared with noninfected ones. However, plants infected by root-knot nematodes showed distorted feeder roots and root galls of large (6 to 8 $\mathrm{mm}$ ) to moderate ( 2 to $3 \mathrm{~mm}$ ) size. Galls occurred either singly or in clusters on the root (Fig. 1B and C).

Mesocriconema xenoplax was found in soil and roots of olive cvs. Arbequina, Manzanilla, and Picual. The population density ranged from 343 to 517 nematodes per 100 $\mathrm{cm}^{3}$ of soil, and from 6 to 23 nematodes per gram of fresh weight of root. $P$. penetrans and $P$. vulnus occurred on all four major olive cultivars, with frequencies ranging from 20.5 to $33.3 \%$ and 11.8 to $40.0 \%$, respectively. The higher frequency of $P$. penetrans occurred in cvs. Manzanilla (33.3\%) and Picual (29.4\%). P. vulnus occurred with higher frequency in cvs. Manzanilla (22.2\%) and Arbequina (20.6\%), and also was found in cv. Cornicabra (4.8\%).

Meloidogyne spp. also occurred in soil and roots of the four major olive cultivars examined, with population densities between 192 and 1,205 second-stage juveniles (c) per $100 \mathrm{~cm}^{3}$ of soil, and 662 to 2,856 eggs and $\mathrm{J}_{2}$ per gram of root (Table 2). Of the different Meloidogyne spp., $M$. arenaria was found infecting cvs. Arbequina and Cornicabra only. Conversely, $M$. incognita and $M$. javanica were found infecting all the major olive cultivars, with the highest frequencies (18.5 and $14.8 \%$, respectively) occurring in 'Manzanilla', and the lowest in 'Cornicabra' $(4.8 \%)$ and 'Picual' (5.9\%). Particularly high populations of $M$. incognita (13 to $393 \mathrm{~J}_{2}$ per 100 $\mathrm{cm}^{3}$ of soil) and M. javanica (163 to $468 \mathrm{~J}_{2}$ per $100 \mathrm{~cm}^{3}$ of soil) were found in the soil samples. Similarly, high populations of these latter species ( 2 to 4,297 eggs and $\mathbf{J}_{2}$ per gram of root for $M$. incognita, and 421 to 1,549 eggs and $J_{2}$ per gram of root for $M$. javanica) were found in roots of all cultivars. M. lusitanica occurred in a single soil and root sample of 'Picual', with population densities of $643 \mathrm{~J}_{2}$ per $100 \mathrm{~cm}^{3}$ of soil and 2,856 eggs and $\mathbf{J}_{2}$ per gram of root, respectively (Table 2).
Other plant-parasitic nematodes that were detected in bulk soil and roots of olive planting stocks included spiral (Helicotylenchus spp.), stunt (Tylenchorhynchus spp., Amplimerlinius spp.), and pin nematodes (Paratylenchus spp.), with population densities ranging from 22 to 779 nematodes per $100 \mathrm{~cm}^{3}$ of soil (Table 2).

Histopathology. Root galls induced by Meloidogyne spp. on olive planting stocks varied in size and location (Fig. 1B and C). Generally, large, irregular galls were present on root tips, but also were present along the root axis (Fig. 1B). In many cases, up to eight mature globose females were found associated with the largest galls (i.e., those produced by $M$. arenaria on 'Cornicabra') (Fig. 1L). Occasionally, an egg mass was found at the root surface (Fig. 1C), but the majority of egg masses were observed inside the cortical root tissues irrespective of age of the plant root system (Fig. 1L). Furthermore, the majority of egg masses found inside the root contained numerous eggs (Fig. 1L).

Comparative histological observation of healthy (Fig. 1D) and Meloidogyne spp.infected (Figs. 1E-L) olive roots showed cellular alterations in tissues of the cortex, endodermis, pericycle, and vascular parenchyma induced by the nematode. In the permanent feeding sites, the nematodeinduced formation of large multinucleate giant cells adjacent to the vascular tissues was observed in all olive cultivars. This formation led to distortion and crushing of tissues (Fig. 1 E-L). Giant cells showed dense cytoplasm and variable numbers of hypertrophied nuclei and nucleoli (Fig. 1I and K). Additionally, hyperplasia of tissues adjacent to giant cells contributed to formation of the observed root galling (Fig. 1F).

\section{DISCUSSION}

The primary objective of this study was to determine the extent of infestation by plant-parasitic nematodes in olive nurseries in the key olive-producing provinces of Andalucía, southern Spain. Our survey results indicate that more than $65 \%$ of the olive planting stocks sampled were infected singly by either Mesocriconema xenoplax, $P$. penetrans, $P$. vulnus, Meloidogyne arenaria, $M$. incognita, or $M$. javanica, and approximately $10 \%$ of the stocks were co-infected by more than one of these nematodes. Little is known about the extent of and potential for damage caused by many of these species to olive. However, Mesocriconema xenoplax, Meloidogyne spp., and Pratylenchus spp. can be damaging to other fruit trees $(21,23,28)$. Population densities of these latter nematode species in soil and olive roots ranged from moderate to high (i.e., 100 to 5,000 eggs and $\mathrm{J}_{2}$ of Meloidogyne spp. per plant, and 50 to 1,000 specimens of Mesocriconema xenoplax and Pratylenchus spp. per plant, respectively). Although damaging population thresholds for these nema- todes to olive planting stocks are unknown, the population densities encountered in our survey may present a potential risk to olive planting stocks in nursery and field conditions when compared with threshold densities reported on other fruit trees $(20,21,28)$. Pathogenicity tests under greenhouse conditions have indicated that moderate to high population densities ( 1,000 to 10,000 $\mathrm{J}_{2}$ per plant) of Meloidogyne incognita and $M$. javanica significantly reduced shoot growth of olive cvs. Ascolano, Manzanilla, and Sevillano (20). Similarly, infections of cv. Manzanilla by $P$. vulnus significantly reduced olive shoot growth (21). Thus, the population densities of root-lesion and root-knot nematodes found in this study have the potential to damage feeder roots, resulting in loss of vigor in young and mature olive trees as reported for other fruit trees (28). Furthermore, potential damage by these nematode populations might be even greater in the irrigated sandy soils of the Guadalquivir Valley of Andalucía, where many new olive plantations are established, because nematode biology and development are favored by the moderate temperature and moist environment prevailing in these soils (19).

Although no nematicide treatment threshold for Mesocriconema xenoplax has been established for olive trees, the nematode frequency detected in the olive cultivar tested warrant further investigations.

Other nematodes found in association with, but not necessarily causing economic damage to olive, include Pratylenchus thornei Sher \& Allen, P. neglectus (Rensch) Filipjev \& Schurrmans Steckhoven, P. fallax Seinhorst, Zygotylenchus guevarai (Tobar Jiménez) Braun \& Loof, Paratylenchus arculatus Luc \& de Guiran, and Paratylenchus microdorus Andrássy.

Finally, four migratory ectoparasitic species, Paratrichodorus minor (Colbran) Siddiqi, Paratrichodorus teres (Hooper) Siddiqi, Trichodorus giennensis Decraemer, Roca, Castillo, Peña-Santiago \& Gómez-Barcina, and Xiphinema pachtaicum (Tulaganov) Kirjanova were found in various olive planting stocks. None of these nematodes are known vectors of Arabis mosaic virus and Strawberry latent ringspot virus, which have been reported on olive (32). These two viruses are transmitted by $X$. diversicaudatum (Micoletzky) Thorne (25), which was not detected in our study. Nevertheless, special attention should be paid to $X$. diversicaudatum in olives grown in southern Spain because this nematode has been reported in central and northern Spain (27). The parasitic habit of P. minor, P. teres, T. giennensis, and $X$. pachtaicum, along with the low population densities found in soil of olive nurseries, suggest that these nematodes pose an unlikely risk to the olive trees industry in Spain.

The "citrus biotype" of $T$. semipenetrans, the only one known to reproduce on 
olive, has not been reported in Spain (34). That we found no T. semipenetrans on olive in our survey substantiates the previous studies (34). This nematode, however, is considered potentially threatening to olive production in California and northern Italy $(15,26)$, where high levels of $T$. semipenetrans have been shown to inhibit olive growth (24). Biotype distribution is determined by host plants rather than ecological factors (34); therefore, care should be taken to avoid the introduction of this nematode into Spain, and particularly in Andalucía, where the three susceptible hosts (i.e., olive, citrus, and grape) are grown commercially and in close proximity.

Our histological studies revealed a typical susceptible reaction of olive cvs. Arbequina, Cornicabra, Hojiblanca, Manzanilla, and Picual to infection by Meloidogyne arenaria, $M$. incognita, and $M$. javanica. The extensive giant cells and modifications of vascular tissues induced by nematode infection sequester nutrients from the host plant and limit water and nutrient translocation from infected roots to aboveground plant tissues (14). The development and parasitic habit of Meloidogyne spp. that we observed on olive planting stocks were similar to that found in 4- to 6-year-old olive orchards in Argentina (11), Italy, and Portugal (1). However, an additional finding in our study was the occurrence of large numbers of egg masses with numerous eggs observed within root tissues rather than as typically noted on the root surface. The embedded egg masses also could contribute to secondary infections when planting stocks are transplanted free of soil. These data further suggest that the roots of young olive plants may be more susceptible to root-knot nematodes than those of 4- to 6-year-old trees, because no similarly embedded Meloidogyne sp. egg masses were reported in studies of 4- to 6year-old olive orchards in Argentina (11) and Portugal (1).

The high level of nematodes found in soil and roots of olive planting stocks, as well as the anatomical alterations observed in infected roots, suggest that parasitism of olive roots by root-lesion and root-knot nematodes may potentially contribute to the decline of olive planting stocks in olive nurseries or new orchards. As a consequence, further studies have been initiated to determine the pathogenicity of root-knot and root-lesion nematodes to olive planting stocks. Also, nematode control measures in olive nurseries (i.e., preplant bare-root dips of seedlings in suspensions of nematicidal chemicals, disinfestation of soil substrates by soil solarization, biofumigation, or nematicides) are recommended to avoid potential nematode problems in new plantations $(22,35)$.

\section{ACKNOWLEDGMENTS}

We thank N. Vovlas and A. Troccoli (CNR, Bari, Italy) and W. Decraemer (Brussels, Belgium) for confirming identification of some nematode species; and E. García-Cuevas Agredano and J. Martín-Barbarroja for technical assistance.

\section{LITERATURE CITED}

1. Abrantes, I. M., Vovlas, N., and Santos, M. S. N. 1992. Host-parasite relationships of Meloidogyne javanica and M. lusitanica with Olea europaea. Nematologica 38:320-327.

2. Barranco, D. 1999. Variedades y patrones. Pages: 63-89. in: El Cultivo del Olivo, 3rd ed. D. Barranco, R. Fernández-Escobar, and L. Rallo, eds. Ediciones Mundi-Prensa. Madrid

3. Bejarano-Alcázar, J., Blanco-López, MeleroVara, J. M., and Jiménez-Díaz, R. M. 1996. Etiology, importance, and distribution of Verticillium wilt of cotton in southern Spain. Plant Dis. 80:1233-1238.

4. BOE. 1999. Modificación del reglamento técnico de control y certificación de plantas de vivero de frutales. Boletin Oficial Estado No. 276:40077-40079.

5. BOJA. 1997. Reglamento Específico de Producción Integrada del Olivar. Boletin Junta Andalucia No. 100:10543-10555.

6. Caballero, J. M., and del Río, C. 1999. Métodos de multiplicación. Pages: 91-115. in: El Cultivo del Olivo, 3rd ed. D. Barranco, R. Fernández- Escobar, and L. Rallo, eds. Ediciones Mundi-Prensa. Madrid.

7. Castillo, P., Vovlas, N., Nico, A. I., and Jiménez-Díaz, R. M. 1999. Infection of olive trees by Heterodera mediterranea in orchards in southern Spain. Plant Dis. 83:710-713.

8. Consejo Oleícola Internacional. 1991. Olive, olive oil, and table olives. COI, Madrid. In Spanish.

9. Coolen, W. A. 1979. Methods for the extraction of Meloidogyne spp. and other nematodes from roots and soil. Pages 319-329 in: Rootknot Nematodes (Meloidogyne species) Systematics, Biology and Control. F. Lamberti and C. E. Taylor, eds. Academic Press, London.

10. Diab, K. A., and El-Eraki, S. 1968. Plantparasitic nematodes associated with olive decline in the United Arab Republic. Plant Dis. Rep. 52:150-154.

11. Doucet, M. E., Ponce de León, E. L., and Poloni, N. 1997. Alteraciones histológicas inducidas por Meloidogyne incognita en raíces de olivo en Catamarca, Argentina. Nematol. Mediterr. 25:275-277.

12. Hartman, K. M., and Sasser, J. N. 1985. Identification of Meloidogyne species on the basis of differential host test and perineal pattern morphology. Pages 69-77 in: An Advanced Treatise on Meloidogyne. Vol. 2. Methodology. K. R. Barker, C. C. Carter, and J. N. Sasser, eds. North Carolina State University Graphics, Raleigh.

13. Hussey, R. S., and Barker, K. R. 1973. A comparison of methods of collecting inocula of Meloidogyne spp., including a new technique. Plant Dis. Rep. 57:1025-1028.

14. Hussey, R. S., and Williamson, V. M. 1997. Physiological and molecular aspects of nematode parasitism. Pages $87-108$ in: Plant and Nematode Interactions. K. R. Barker, G. A. Pederson, and G. L. Windham, eds. American Society of Agronomy, Inc., Madison, WI.

15. Inserra, R. N., and Vovlas, N. 1981. Indagine sulla distribuzione geografica dei nematodi parassiti dell'olivo in Italia. Infor. Fitopatol. 1:117-119.

16. Inserra, R. N., Vovlas, N., Fontanazza, G., and Lacasta, G. 1981. Comportamento di alcune cultivar di olivo alle infestazioni di quatro specie di nematodi. Riv. Ortoflorofrutti. Ital. 65:143-148.

17. Jensen, W. A. 1962. Botanical Histochemistry.
W. H. Freeman and Co., San Francisco.

18. Jiménez-Díaz, R. M., Tjamos, E. C., and Cirulli, M. 1998. Verticillium wilts of major tree hosts. Pages 13-16 in: A Compendium of Verticillium Wilts in Tree Species. J. H. Hiemstra and D. C. Harris eds. Ponsen and Looijen, Wageningen, The Netherlands.

19. Koenning, S. R., Walters S. A., and Barker K. R. 1996. Impact of soil texture on the reproductive and damage potentials of Rotylenchulus reniformis and Meloidogyne incognita on cotton. J. Nematol. 28:527-536.

20. Lamberti, F., and Baines, R. C. 1969. Pathogenicity of four species of Meloidogyne on three varieties of olive trees. J. Nematol. 1:111-115.

21. Lamberti, F., and Baines, R. C. 1969. Effect of Pratylenchus vulnus on the growth of 'Ascolano' and 'Manzanillo' olive trees in a glasshouse. Plant Dis. Rep. 53:557-558.

22. Lamberti, F., and Di Vito, M. 1972. Sanitation of root-knot nematode infected olive-stocks. Pages 401-411 in: Actas III Congr. Uniao Fitopatol. Mediterr. Oeiras, Portugal.

23. Lamberti, F., and Vovlas, N. 1993. Plan parasitic nematodes associated with olive. EPPO Bull. 23:481-488.

24. Lamberti, F., Vovlas, N., and Tirro, A. 1976. Infettivita e patogenicita de tre popolazion italiane di Tylenchulus semipenetrans su agrumi ed altri ospidi. Nematol. Mediterr. 4:85-91.

25. Martelli, G., and Taylor, C. E. 1989. Distribution of viruses and their nematode vectors. Pages: 151-189 in: Advances in Disease Vector Research. G. Martelli, ed. Springer-Verlag, New York.

26. McKenry, M. V. 1994. Nematodes of Olive Pages 97-99 in: Olive Production Manual. L. Ferguson, G. S. Sibett, and G. C. Martin, eds. University of California, Oakland, Publ. 3353.

27. Navas, A., Bello, A., and Arias, M. 1988. Ecology and potential distribution of Xiphinema diversicaudatum and $X$. pachtaicum (Nematoda: Longidoridae) in continental Spain. Nematologica 34:314-330.

28. Nyczepir, A. P., and Halbrendt, J. M. 1993. Nematode pest of deciduous fruit and nut trees. Pages 381-425 in: Plant-Parasitic Nematode in Temperate Agriculture. K. Evans, D. L. Trudgill, and J. M. Webster, eds CAB International, Cambridge, UK

29. OEPP/EPPO 1993. Certification schemes. No. 7. Nursery requirements- recommended requirements for establishments participating in certification of fruit or ornamental crops. Bull. OEPP/EPPO Bull. 23:249-252.

30. Rodríguez-Jurado, D., Blanco-López, M. A., Rapoport, H. F., and Jiménez-Díaz, R. M. 1993. Present status of Verticillium wilt of olive in Andalucía (southern Spain). Bull. OEPP/EPPO Bull. 23:513-516.

31. Seinhorst, J. W. 1962. On the killing, fixation and transferring to glycerine of the nematodes. Nematologica 8:29-32.

32. Taylor, C. E., and Brown, D. J. F. 1997. Nematode Vectors of Plant Viruses. CAB International. Cambridge, UK.

33. Thanassoulopoulos, C. C. 1993. Spread of Verticillium wilt by nursery plants in olive groves in the Halkidiki area (Greece). Bull. OEPP/EPPO Bull. 23:517-520.

34. Verdejo-Lucas, S., Sorribas, F. J., Pons, J., Forner, J. B., and Alcaide, A. 1997. The Mediterranean biotypes of Tylenchus semipenenetrans in Spanish citrus orchards. Fundam. Appl. Nematol. 20:399-404.

35. Vovlas, N., Inserra, R., and Lamberti, F. 1975. Risanamento di piantoni di arancio amaro, olivo e vite infestati da nematodi. Atti. Giornate. Fitopatol. 271-277. 